Article

\title{
Structural and Functional Characterization of Conotoxins from Conus achatinus Targeting NMDAR
}

\author{
Xiujie Liu, Ge Yao, Kang Wang, Yanli Liu, Xiukun Wan 1 and Hui Jiang * \\ State Key Laboratory of NBC Protection for Civilian, Beijing 102205, China \\ * Correspondence: jiangtide@sina.cn
}

Received: 23 January 2020; Accepted: 24 February 2020; Published: 26 February 2020

check for updates

\begin{abstract}
Conotoxin-Ac1 and its variant conotoxin-Ac1-O6P, were isolated from the venom duct of Conus achatinus, a fish-hunting cone snail species collected in the Sea of Hainan, China. Conotoxin-Ac1 is linear peptide that contain 15 amino acids. In the present study, we synthesized and structurally and functionally characterized conotoxin-Ac1 as well as 19 variants. Electrophysiological results showed that conotoxin-Ac1 inhibited N-methyl-D-aspartate receptor subunit $2 \mathrm{~B}$ (NR2B) with an $\mathrm{IC}_{50}$ of $8.22 \pm 0.022 \mu \mathrm{M}$. Further structure-activity studies of conotoxin-Ac demonstrated that polar amino acid residues were important for modulating its active, and the replacement of N1, O9, E10, and S12 by Ala resulted in a significant decrease in potency to NR2B. ${ }^{\circ}$ Furthermore, conotoxin-Ac1 and conotoxin-Ac1-O6P were tested in hot-plate and tail-flick assays to measure the potential analgesic activity to an acute thermal stimulus in a dose-dependent manner. Subsequently, the analgesic activity of conotoxin-Ac1 mutants was analyzed by the hot-plate method. The results show that N1, Y2, Y3, E10, N11, S12, and T15 play an important role in the analgesic activity of conotoxin-Ac1. N1 and S12 have significant effects on conotoxin-Ac1 in inhibiting NR2B and analgesic activity. In conclusion, we have discovered that conotoxin-Ac1 is an inhibitor of NMDAR and displays antinociceptive activity.
\end{abstract}

Keywords: conotoxins; N-methyl-D-aspartate receptor; structure-activity relationship; Conus achatinus

\section{Introduction}

Conotoxins (CTxs) are highly sophisticated set of neuropharmacological weapons formed during the long-term evolution. Most of the CTxs are composed of 12 to 40 amino acid residues and contain 2 to 3 pairs of disulfide bonds. CTxs are among smallest nucleic acid-encoded animal neurotoxin peptides, and they are also small peptides with the highest disulfide bond density [1]. CTxs can specifically act on voltage-gated ion channels $\left(\mathrm{Na}^{+}, \mathrm{K}^{+}, \mathrm{Ca}^{2+}\right)$, ligand-gated ion channels (nAchR, $5-\mathrm{HT}_{3} \mathrm{R}, \mathrm{NMDAR}$ ) and $\mathrm{G}$ protein-coupled receptors (neurotensin receptors and vasopressin receptors), have received extensive attention in the field of neuroscience and new drug development. For example, $\alpha, \alpha \mathrm{A}$, and $\psi$-CTxs antagonize nAchR competitively and noncompetitively [2]. $\omega$-CTxs selectively inhibit various subtypes of voltage-sensitive $\mathrm{Ca}^{2+}$ channels [3]. $\mathrm{K}$-CTxs selection the voltage-sensitive $\mathrm{K}^{+}$channel are inhibited [4], while $\mu$ and $\mu \mathrm{O}-\mathrm{CT}$ xs selectively act on the voltage-sensitive $\mathrm{Na}^{+}$ channel [5-7]. In addition, some Conotoxins, which do not contain or contain a pair of disulfide bonds, can selectively act on vasopressin receptors (such as conopressin) [8], NMDA receptors (such as conantokins) [9], serotonin type 3 (5-HT3) receptors [10]. CTxs can distinguish and recognize many different subtypes or heterostructures of ion channels and neural receptors and are widely used in life science research; several CTxs have been marketed or entered clinical research as analgesics and antiepileptic drugs. According to their feeding habits, cone snails are either fish-hunting (piscivorous class), mollusk-hunting (molluscivorous class), or worm-hunting (vermivorous class). Fish-hunting cone snails are not the largest category of cone snails, but the activity of CTxs on mammals is obvious. There are many types of cone snails, and each type of cone snails contains different toxins. Therefore, 
studying new species of cone snails means obtaining a new structure of toxins, which means that it may have new functions. Conus achatinus is a fish-hunting cone snails. At present, little research has been conducted at home and abroad on the toxins of this cone snail [11-13]. We have conducted preliminary research, taking advantage of the South China Sea resources to purify and characterize a class of containing D-amino acid CTxs. We also explored the role of these CTxs in ion channels and analgesic activity.

\section{Results}

\subsection{Isolation, Purification and Sequencing of CTXs}

\subsubsection{Isolation and Purification of CTxs}

A $2.95 \mathrm{mg}$ crude sample was obtained from the venom tube of two cone snails. The crude fraction was obtained with Superdex Peptide to obtain eight main fractions (Supplemental Figure S1). Considering the abundance of the sample, fraction \#5 was taken as the research object. The collected fraction \#5 was analyzed by HPLC, and the two toxins 5P1 and 5P2 were mainly contained in fraction \#5 (Supplemental Figure S2). These toxins were separated and purified to obtain high-purity samples $5 \mathrm{P} 1$ and $5 \mathrm{P} 2$.

\subsubsection{Sequencing of CTxs}

MALDI-TOF-MS was used to measure the molecular weights of the two CTxs. After reducing the derivative with DTT and 4-vinylpyridine and measuring the molecular weight, it was found that the molecular weights of 5P1 and 5P2 did not change before and after derivatization, indicating no cysteine. For the amino acid, the molecular weight of 5P1 is 1992.11, and the molecular weight of 5P2 is 1976.11. $5 \mathrm{P} 1$ weighs 16 Da more than 5P2. 5P2 is a variant of 5P1 that lacks a single modification of proline hydroxylation. Next, $2 \mu \mathrm{g}$ of each is obtained for sequencing and to determine its primary structure:

\section{P1: NYYLYOAROENSWWT} 5P2: NYYLYPAROENSWWT

The natural 5P2 was hydrolyzed by carboxypeptidase: Since carboxypeptidase cannot hydrolyze D-type amino acids, the termination site is the D-amino residue. As shown in the results, hydrolysis was stopped when W13 was reached, and W13 was judged to be D-shaped. According to this judgment, the primary structure of 5P2 should be NYYLYPAROENSWWT, where W is a D-amino acid, $\mathrm{O}$ is hydroxyproline. Chemically synthesized 5P2, identified by HPLC, was able to coelute with natural toxin 5P2, indicating a consistent structure. The same strategy was used to synthesize 5P1: NYYLYOAROENSWWT, which was identified by HPLC as coeluting with the natural toxin 5P1, indicating a consistent structure (Supplemental Figures S3 and S4). 5P1 and 5P2 are mature peptides, isolated from Conus achatinus.Using NCBI website, multimode search was conducted, the full-length precursor sequence of 5P1 and 5P2 was found. Wu et al [14] reported that Ac3.1 was identified by cDNA, and the deduced amino acid sequences of the cloned conotoxins Ac3.1: LGVLVTIFLVLFPMATLQLDGDQTADRHAGERDQDPLEQYRNLKHVLRRTRNYYLYPARPENSWWT. Based on Ac3.1, we named 5P1 as conotoxin-Ac1, and 5P2 is the variant of 5P1, named 5P2 as conotoxin-Ac1-O6P.

\subsection{Chemical Synthesis of Conotoxin-Ac1, Its Variant and Its Mutants}

According to the sequence of each peptide in Table 1, peptides were synthesized by solid-phase synthesis. The purity of each peptide was greater than 95\% after HPLC analysis and determined by mass spectrometry (Supplemental MS data). The overall conformation of $20 \mathrm{CT}$ xs was examined by CD spectroscopy (Table 2). The secondary structure of conotoxin-Ac1 was $44.9 \% \alpha$-helix, $27.7 \% \beta$-sheet, $15 \% \beta$-turn and $12.4 \%$ random coil. Interestingly, the secondary structure of conotoxin-Ac1-Y5A was 
$46.8 \% \beta$-sheet, $27.3 \% \beta$-turn, $17.8 \%$ random coil, and $8.1 \% \alpha$-helix. The percentages of $\beta$-sheets and $\beta$-turns in conotoxin-Ac1-Y5A are higher than those in conotoxin-Ac1, and the percentage of $\alpha$-helices in conotoxin-Ac1-Y5A is considerably lower than that in conotoxin-Ac1. The secondary structures of 19 CTxs-except for conotoxin-Ac1-Y5A-are mainly $\alpha$-helices and $\beta$-sheets. Only $41.2 \%$ of the $\alpha$-helices of conotoxin-Ac1-O9A and 37.1\% of the $\alpha$-helices of conotoxin-Ac1-E10A are lower than $44.9 \%$ of the $\alpha$-helices of conotoxin-Ac1.

Table 1. The amino acid sequences of conotoxin-Ac1, its variant and its mutants.

\begin{tabular}{cccc}
\hline No. & Name & Molecular Weight & Sequence \\
\hline 1 & conotoxin-Ac1 & 1992.11 & NYYLYOAROENSWWT \\
2 & conotoxin-Ac1-O6P & 1976.11 & NYYLYPAROENSWWT \\
3 & conotoxin-Ac1-N1A & 1758.84 & AYYLYOAROENSWWT \\
4 & conotoxin-Ac1-Y2A & 1705.77 & NAYLYOAROENSWWT \\
5 & conotoxin-Ac1-Y3A & 1705.77 & NYALYOAROENSWWT \\
6 & conotoxin-Ac1-L4A & 1755.79 & NYYAYOAROENSWWT \\
7 & conotoxin-Ac1-Y5A & 1705.77 & NYYLAOAROENSWWT \\
8 & conotoxin-Ac1-O6A & 1852.95 & NYYLYAAROENSWWT \\
9 & conotoxin-Ac1-R8A & 1712.76 & NYYLYOAAOENSWWT \\
10 & conotoxin-Ac1-O9A & 1852.95 & NYYLYOARAENSWWT \\
11 & conotoxin-Ac1-E10A & 1739.83 & NYYLYOAROANSWWT \\
12 & conotoxin-Ac1-N11A & 1754.84 & NYYLYOAROEASWWT \\
13 & conotoxin-Ac1-S12A & 1781.87 & NYYLYOAROENAWWT \\
14 & conotoxin-Ac1-W13A & 1682.73 & NYYLYOAROENSAWT \\
15 & conotoxin-Ac1-W14A & 1682.73 & NYYLYOAROENSWAT \\
16 & conotoxin-Ac1-T15A & 1767.84 & NYYLYOAROENSWWA \\
17 & conotoxin-Ac1-15 * & 1796.88 & NYYLYOAROENSWWT * \\
18 & conotoxin-Ac1-E10 $\gamma$ & 1797.87 & NYYLYOARO $\gamma N S W W T$ \\
19 & conotoxin-Ac1-E10 $\gamma W 14 \gamma$ & 1740.77 & NYYLYOARO $\gamma$ NSW $\gamma$ T \\
20 & conotoxin-Ac1- E10 $\gamma W 14 \gamma 15 *$ & 1739.77 & NYYLYOARO ${ }^{*}$ NSW $\%{ }^{*}$ \\
\hline
\end{tabular}

${ }^{*}$ C-terminal amidation; $\gamma$ : $\gamma$-carboxyglutamic acid; W: D-type tryptophan; O: hydroxyproline.

Table 2. CD spectrum analysis of conotoxin-Ac1, its variant and its mutants.

\begin{tabular}{|c|c|c|c|c|c|}
\hline No. & Name & $\alpha$-helix (\%) & $\beta$-sheet (\%) & $\beta$-turn (\%) & Random Coil (\%) \\
\hline 1 & conotoxin-Ac1 & 44.9 & 27.7 & 15 & 12.4 \\
\hline 2 & conotoxin-Ac1-O6P & 51 & 21.9 & 16.1 & 11 \\
\hline 3 & conotoxin-Ac1-N1A & 54.7 & 35 & 8.1 & 2.2 \\
\hline 4 & conotoxin-Ac1-Y2A & 48.4 & 23.4 & 16.3 & 11.9 \\
\hline 5 & conotoxin-Ac1-Y3A & 48.9 & 23 & 16.6 & 11.5 \\
\hline 6 & conotoxin-Ac1-L4A & 49.6 & 25.7 & 13.2 & 11.5 \\
\hline 7 & conotoxin-Ac1-Y5A & 8.1 & 46.8 & 27.3 & 17.8 \\
\hline 8 & conotoxin-Ac1-O6A & 46.6 & 26.6 & 6.4 & 20.4 \\
\hline 9 & conotoxin-Ac1-R8A & 54.4 & 23.5 & 14.1 & 8 \\
\hline 10 & conotoxin-Ac1-O9A & 41.2 & 27.4 & 16.2 & 15.2 \\
\hline 11 & conotoxin-Ac1-E10A & 37.1 & 30.2 & 16.1 & 16.6 \\
\hline 12 & conotoxin-Ac1-N11A & 51.1 & 24.6 & 14.3 & 10 \\
\hline 13 & conotoxin-Ac1-S12A & 46.7 & 25.9 & 16.8 & 10.6 \\
\hline 14 & conotoxin-Ac1-W13A & 49.2 & 16.2 & 23.1 & 11.5 \\
\hline 15 & conotoxin-Ac1-W14A & 45.9 & 23.1 & 16.6 & 14.4 \\
\hline 16 & conotoxin-Ac1-T15A & 49 & 21.3 & 13.6 & 16.1 \\
\hline 17 & conotoxin-Ac1-15 * & 48.7 & 26.7 & 12.7 & 11.9 \\
\hline 18 & conotoxin-Ac1-E10 $\gamma$ & 50.7 & 23.1 & 9.4 & 16.8 \\
\hline 19 & conotoxin-Ac1-E10 $\gamma \mathrm{W} 14 \gamma$ & 52.9 & 26.8 & 9.9 & 10.4 \\
\hline 20 & conotoxin-Ac1-E10 $\gamma \mathrm{W} 14 \gamma 15^{*}$ & 47.2 & 18.2 & 18.1 & 16.5 \\
\hline
\end{tabular}

* C-terminal amidation; $\gamma: \gamma$-carboxyglutamic acid; O: hydroxyproline. 


\subsection{Electrophysiology Experiment}

\subsubsection{Conotoxin-Ac1 and Conotoxin-Ac1-O6P act on NMDAR Ion Channels}

The hippocampus of newborn SD rats was isolated, and hippocampal neuron cells were obtained. After incubation, the effect of $10 \mu \mathrm{M}$ conotoxin-Ac1 and conotoxin-Ac1-O6P on the activity of $\mathrm{Na}^{+}, \mathrm{K}^{+}$, $\mathrm{Ca}^{2+}$, and NMDAR ion channels was analyzed using whole-cell patch-clamp technology (Table 3). The experimental results show that conotoxin-Ac1 and conotoxin-Ac1-O6P have almost no inhibitory effect on $\mathrm{Na}^{+}$and $\mathrm{K}^{+}$, conotoxin-Ac1-O6P has a relatively low inhibitory effect on $\mathrm{Ca}^{2+}$ ion channels, conotoxin-Ac1 and conotoxin-Ac1-O6P have the most obvious inhibitory activity on NMDAR ion channels, and $10 \mu \mathrm{M}$ conotoxin-Ac1 inhibited the current of NMDAR ion channels by $56.90 \%$. Therefore, we believe that conotoxin-Ac1 and conotoxin-Ac1-O6P act on the NMDAR ion channel.

Table 3. The electrophysiological result of 5P1 and conotoxin-Ac1-O6P inhibiting ion channels.

\begin{tabular}{ccccccc}
\hline \multirow{2}{*}{ Groups } & \multicolumn{6}{c}{ The Inhibition of Currents (\%) } \\
\cline { 2 - 7 } & Nav & Kv & Cav & NMDAR & NR2A & NR2B \\
\hline $10 \mu \mathrm{M}$ conotoxin-Ac1 & 0.55 & 5.50 & 6.70 & 56.90 & 7.22 & 51.69 \\
$10 \mu \mathrm{M}$ conotoxin-Ac1-O6P & 2.69 & 5.71 & 17.89 & 14.37 & 1.85 & 10.63 \\
\hline
\end{tabular}

\subsubsection{Conotoxin-Ac1 and Conotoxin-Ac1-O6P Act on the NR2A and NR2B Subtype}

HEK293 cells stably expressing NR2B/NR2A were used, and the effect of $10 \mu \mathrm{M}$ conotoxin-Ac1 on the activity of NR2A and NR2B ion channels was analyzed by the whole-cell patch clamp technique (Table 3). The experimental results show that $10 \mu \mathrm{M}$ conotoxin-Ac1 has a higher activity inhibition rate of NR2B ion channels of up to $51.69 \%$, while a lower activity inhibition rate of NR2A ion channels, that is, only $7.22 \%$. Conotoxin-Ac1 has a high inhibition rate to NR2B than NR2A. The inhibition rate of NR2A and NR2B ion channels was lower in $10 \mu \mathrm{M}$ conotoxin-Ac1-O6P. The difference between conotoxin-Ac1 and conotoxin-Ac1-O6P is that only the amino acid residue at position 6 in conotoxin-Ac1 is hydroxyproline, the amino acid residue at position 6 in conotoxin-Ac1 is proline, and the percentage of inhibition of the NR2B ion channel activity between $10 \mu \mathrm{M}$ conotoxin-Ac1 and $10 \mu \mathrm{M}$ conotoxin-Ac1-O6P is different by almost five-fold. The experimental results show that the hydroxyproline residue at position 6 in conotoxin-Ac1 is its key active amino acid residue, which plays an important role in inhibiting NR2B activity.

\subsubsection{Effect of Conotoxin-Ac1 Mutants on NR2B}

HEK293 cells stably expressing NR2B/NR2A were used, and the activity inhibition rate of conotoxin-Ac1 on NR2B ion channels was analyzed by the whole-cell patch clamp technique. The experimental results are shown in the figure. The $\mathrm{IC}_{50}$ value of conotoxin-Ac1 on the activity of NR2B ion channels is $8.22 \pm 0.022 \mu \mathrm{M}$ (Figure 1). In this work, the patch clamp technique was used to detect the influence of conotoxin-Ac1, its variant, and its mutants on NR2B in HEK293 cells. The results showed that conotoxin-Ac1, its variant, and its mutants could induce NR2B channel closure. We also analyzed the affinities of conotoxin-Ac1 mutants with human NR2B (Table 4). Compared with conotoxin-Ac1, the affinity between human NR2B and conotoxin-Ac1 mutants was significantly reduced. Although the affinity between the human NR2B and conotoxin-Ac1 mutants was weaker, the affinity of most mutants and conotoxin-Ac1 was on the same order of magnitude. The inhibition of conotoxin-Ac1-S12A was 25 times weaker than that of conotoxin-Ac1, and the affinity of NR2B and conotoxin-Ac1-N1A (3) or conotoxin-Ac1-O9A (10) or conotoxin-Ac1-E10A (11) was almost 10 times weaker than that of conotoxin-Ac1. The inhibition of conotoxin-Ac1-15* (17), conotoxin-Ac1-E10 $\gamma$ (18), conotoxin-Ac1-E10 $\gamma \mathrm{W} 14 \gamma(19)$ and conotoxin-Ac1-E10 $\gamma \mathrm{W} 14 \gamma 15^{*}(20)$ was clearly weaker than that of conotoxin-Ac1. 


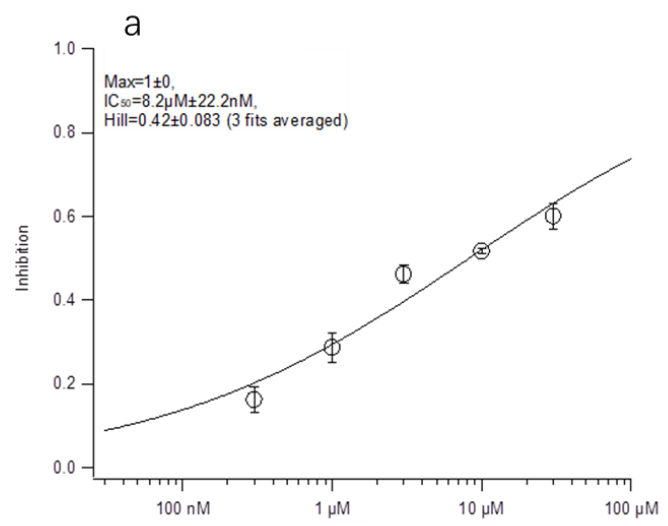

$\mathrm{b}$

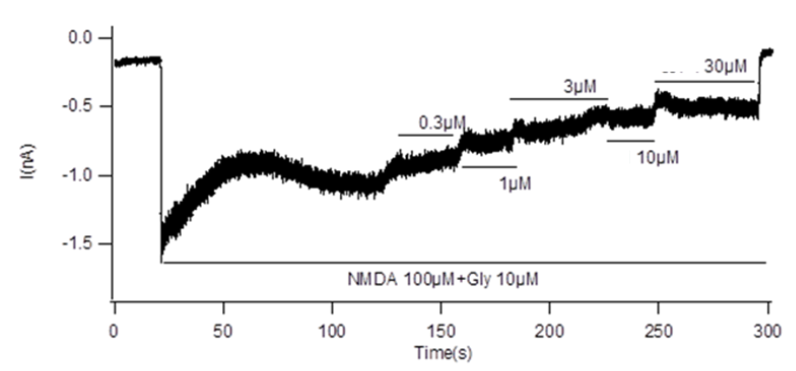

Figure 1. Effect of conotoxin-Ac1 on NR2B in HEK293 cells by Electrophysiology experiment. (a) The dose-response relationship of the effects of conotoxin-Ac1 on NR2B. (b) Electrophysiological profile of conotoxin-Ac1 on NR2B.

Table 4. The electrophysiological result of conotoxin-Ac1, its variant and its mutants inhibiting NR2B $($ Mean $\pm \mathrm{SD})$.

\begin{tabular}{|c|c|c|c|c|c|}
\hline No. & Name & $\begin{array}{l}\text { The Inhibition of } \\
\text { NR2B Currents (\%) }\end{array}$ & No. & Name & $\begin{array}{c}\text { The Inhibition of } \\
\text { NR2B Currents (\%) }\end{array}$ \\
\hline 1 & conotoxin-Ac1 & $51.69 \pm 7.62$ & 11 & conotoxin-Ac1-E10A & $6.54 \pm 0.07$ \\
\hline 2 & conotoxin-Ac1-O6P & $10.63 \pm 1.52$ & 12 & conotoxin-Ac1-N11A & $14.29 \pm 0.93$ \\
\hline 3 & conotoxin-Ac1-N1A & $6.43 \pm 0.50$ & 13 & conotoxin-Ac1-S12A & $2.09 \pm 0.75$ \\
\hline 4 & conotoxin-Ac1-Y2A & $12.54 \pm 1.59$ & 14 & conotoxin-Ac1-W13A & $10.65 \pm 0.57$ \\
\hline 5 & conotoxin-Ac1-Y3A & $9.90 \pm 0.54$ & 15 & conotoxin-Ac1-W14A & $15.72 \pm 0.96$ \\
\hline 6 & conotoxin-Ac1-L4A & $9.99 \pm 0.71$ & 16 & conotoxin-Ac1-T15A & $13.39 \pm 1.29$ \\
\hline 7 & conotoxin-Ac1-Y5A & $12.54 \pm 0.26$ & 17 & conotoxin-Ac1-15 * & $3.30 \pm 2.51$ \\
\hline 8 & conotoxin-Ac1-O6A & $18.98 \pm 2.13$ & 18 & conotoxin-Ac1-E10 $\gamma$ & $4.20 \pm 1.61$ \\
\hline 9 & conotoxin-Ac1-R8A & $8.12 \pm 0.91$ & 19 & conotoxin-Ac1-E10 $\gamma \mathrm{W} 14 \gamma$ & $5.14 \pm 2.68$ \\
\hline 10 & conotoxin-Ac1-O9A & $4.27 \pm 1.97$ & 20 & conotoxin-Ac1-E10 $\gamma \mathrm{W} 14 \gamma 15^{*}$ & $7.63 \pm 0.50$ \\
\hline
\end{tabular}

${ }^{*}$ C-terminal amidation; $\gamma: \gamma$-carboxyglutamic acid; O: hydroxyproline.

\subsection{Animal Experiment}

\subsubsection{Overall Animal Activity of Conotoxin-Ac1 and Conotoxin-Ac1-O6P}

Both CTxs, conotoxin-Ac1 and conotoxin-Ac1-O6P, showed signs of mental weakness and a sluggish response after lateral brain administration. The time of disappearance of the righting reflex in mice was time (Table 5). The experimental results showed that recorded as sleep latency, and the duration of disappearance of the righting reflex was recorded as sleep after the lateral brain injection of conotoxin-Ac1 and conotoxin-Ac1-O6P, the sleep latency of the mice was significantly shortened, while the sleep time was longer than that of the control group, but the difference was statistically significant. The sleep time of the two groups of low-dose mice was longer than $10 \mathrm{~min}$, while the sleep time of the conotoxin-Ac1 high-dose group was $36.87 \mathrm{~min}$, which was longer than the $21.54 \mathrm{~min}$ of the conotoxin-Ac1 high-dose group, and the difference was significant, suggesting that conotoxin-Ac1 has higher overall animal activity than conotoxin-Ac1-O6P.

Table 5. The overall animal activity of conotoxins conotoxin-Ac1 and conotoxin-Ac1-O6P((Mean \pm SD).

\begin{tabular}{ccc}
\hline Group & Sleep Latency (min) & Sleep Time (min) \\
\hline control & $12.55 \pm 1.23$ & $3.27 \pm 1.01$ \\
conotoxin-Ac1 $250 \mu \mathrm{g} / \mathrm{kg}$ & $3.62 \pm 0.54^{* *}$ & $14.81 \pm 4.69^{* *}$ \\
conotoxin-Ac1 $500 \mu \mathrm{g} / \mathrm{kg}$ & $1.64 \pm 0.48^{* *}$ & $36.87 \pm 5.82^{* *}$ \\
conotoxin-Ac1-O6P $250 \mu \mathrm{g} / \mathrm{kg}$ & $4.15 \pm 2.06^{* *}$ & $12.49 \pm 4.28^{* *}$ \\
conotoxin-Ac1-O6P $500 \mu \mathrm{g} / \mathrm{kg}$ & $2.03 \pm 1.35^{* *}$ & $21.54 \pm 6.72^{* *}$ \\
\hline
\end{tabular}

** $p<0.01$ vs. the control group. 


\subsubsection{Animal Analgesic Activity}

Analgesic Activity of Conotoxin-Ac1 and Conotoxin-Ac1-O6P Detected by the Hot-plate Method

Before the experiment, female mice with a normal pain threshold $<30 \mathrm{~s}$ were preselected and randomly divided into 8 groups of 6 mice in each group. Each group was administered by lateral injection (Figure 2a,b and Supplemental Table S1). The pain threshold was 15, 30, 60, 120, and $180 \mathrm{~min}$ after the drug, and the t-test was performed with the normal saline group. As shown in Figure 2, lateral injection of conotoxin-Ac1 and conotoxin-Ac1-O6P at 10, 20, and $40 \mu \mathrm{g} / \mathrm{kg}$ doses after 15, 30, 60, 120, and $180 \mathrm{~min}$ significantly increased the pain threshold, and there were significant differences compared with normal saline. The pain thresholds were all lower than the positive control, $1 \mathrm{mg} / \mathrm{kg}$ morphine.
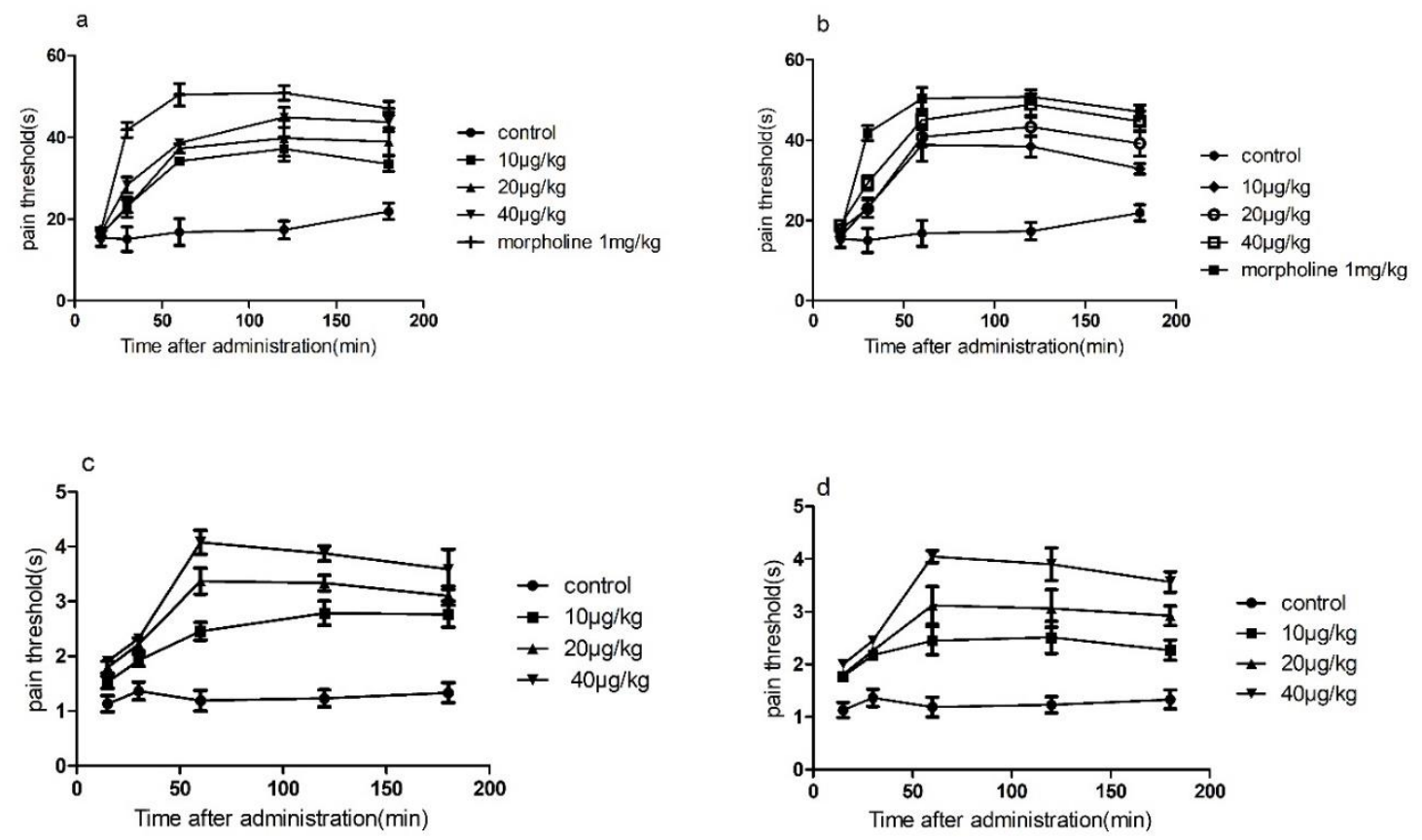

Figure 2. The time course of the dose-dependent analgesic effect of conotoxin-Ac1 and conotoxinAc1-O6P in mice. (a) The dose-dependent analgesic effect of conotoxin-Ac1 by hot-plate method. (b) The dose-dependent analgesia effect of conotoxin-Ac1-O6P by hot-plate method. (c) The dose-dependent analgesic effect of conotoxin-Ac1 by tail-flick method. (d) The dose-dependent analgesia effect of conotoxin-Ac1-O6P by tail-flick method.

Analgesic Activity of Conotoxin-Ac1 and Conotoxin-Ac1-O6P Detected by the Tail-flick Method

Before the experiment, female mice with a normal pain threshold $<1 \mathrm{~s}$ were preselected and randomly divided into 7 groups of 6 mice each. The tail-flick time of the mice was recorded at 15, 30, 60, 120, and $180 \mathrm{~min}$ after administration (Figure 2c,d and Supplemental Table S2). Pain thresholds were calculated at 15, 30, 60, 120, and $180 \mathrm{~min}$ after administration, and t-tests were performed with the saline group. As shown in Figure 2, lateral injection of conotoxin-Ac1 and conotoxin-Ac1-O6P at 10,20 , and $40 \mu \mathrm{g} / \mathrm{kg}$ doses after 15, 30, 60, 120, and $180 \mathrm{~min}$ significantly increased the pain threshold, and there were significant differences compared with the normal saline group. However, the pain threshold of each group was lower than the positive control, $1 \mathrm{mg} / \mathrm{kg}$ morphine.

Analgesic Activity of Conotoxin-Ac1 Mutants Detected by the Hot-plate Method

Time-analgesic activity showed that the conotoxin-Ac1 mutants had an analgesic effect after $30 \mathrm{~min}$ of administration, and the analgesic effect was best after $1-2 \mathrm{~h}$ of administration. Each conotoxin-Ac1 mutants had a sustained analgesic effect at a dose of $10 \mu \mathrm{g} / \mathrm{kg}$ for more than $3 \mathrm{~h}$ (Table 6). The conotoxin-Ac1 mutants modified according to the alanine replacement method have analgesic effects 
less than conotoxin-Ac1, and only conotoxin-Ac1-E10A (11) and conotoxin-Ac1-T15A (16) after $60 \mathrm{~min}$ of administration, the pain threshold is lower than conotoxin-Ac1, and there is a significant difference $(p<0.05)$. In addition, the analgesic effects of conotoxin-Ac1-15* (17), conotoxin-Ac1-E10 $\gamma(18)$, conotoxin-Ac1-E10 $\gamma \mathrm{W} 14 \gamma(19)$, and conotoxin-Ac1-E10 $\gamma \mathrm{W} 14 \gamma 15^{*}(20)$ are better than conotoxin-Ac1, and conotoxin-Ac1-E10 $\gamma \mathrm{W} 14 \gamma(19)$ and conotoxin-Ac1-E10 $\gamma \mathrm{W} 14 \gamma 15^{*}(20)$ are administered for $30 \mathrm{~min}$. The pain thresholds after 30,60,120, and 180 min were significantly higher than the pain thresholds of conotoxin-Ac1 $(p<0.05$ or $p<0.01)$. conotoxin-Ac1-E10 $\gamma W 14 \gamma 15^{*}(20)$ was administered at 60 and $120 \mathrm{~min}$. The pain threshold after $180 \mathrm{~min}$ was better than that of the positive control (morphine).

Table 6. Analgesic activity of conotoxin-Ac1 and conotoxin-Ac1-O6P, as determined by the hot-plate test $(\bar{x} \pm \mathrm{s})$.

\begin{tabular}{|c|c|c|c|c|c|c|}
\hline \multirow{2}{*}{ No. } & \multirow{2}{*}{ Group } & \multicolumn{5}{|c|}{ Pain Threshold (s) } \\
\hline & & $15 \mathrm{~min}$ & $30 \mathrm{~min}$ & $60 \mathrm{~min}$ & $120 \mathrm{~min}$ & $180 \mathrm{~min}$ \\
\hline & control & $15.39 \pm 5.03$ & $13.21 \pm 4.56$ & $15.14 \pm 4.63$ & $12.71 \pm 4.64$ & $21.91 \pm 4.93$ \\
\hline & morpholine 1mg/kg & $17.19 \pm 2.22$ & $41.80 \pm 4.58$ & $50.41 \pm 6.59$ & $50.82 \pm 4.35$ & $47.11 \pm 4.04$ \\
\hline 1 & conotoxin-Ac1 & $16.17 \pm 2.49$ & $23.16 \pm 3.80$ & $34.18 \pm 2.35$ & $37.19 \pm 7.31$ & $33.51 \pm 4.66$ \\
\hline 2 & conotoxin-Ac1-O6P & $15.84 \pm 1.76$ & $23.19 \pm 5.92$ & $38.90 \pm 10.09$ & $38.47 \pm 6.59$ & $33.44 \pm 1.72$ \\
\hline 3 & conotoxin-Ac1-N1A & $17.33 \pm 3.77$ & $21.34 \pm 7.15$ & $34.71 \pm 6.91$ & $32.13 \pm 9.19$ & $28.26 \pm 9.14$ \\
\hline 4 & conotoxin-Ac1-Y2A & $16.81 \pm 1.56$ & $22.28 \pm 3.40$ & $36.77 \pm 8.12$ & $33.84 \pm 7.51$ & $29.90 \pm 7.51$ \\
\hline 5 & conotoxin-Ac1-Y3A & $17.56 \pm 2.49$ & $23.60 \pm 8.28$ & $35.95 \pm 7.67$ & $32.14 \pm 6.87$ & $28.77 \pm 6.32$ \\
\hline 6 & conotoxin-Ac1-L4A & $17.70 \pm 2.71$ & $23.05 \pm 7.12$ & $34.09 \pm 6.75$ & $37.28 \pm 5.09$ & $34.44 \pm 4.78$ \\
\hline 7 & conotoxin-Ac1-Y5A & $16.45 \pm 4.79$ & $21.88 \pm 11.18$ & $31.76 \pm 9.33$ & $32.09 \pm 6.26$ & $30.40 \pm 6.01$ \\
\hline 8 & conotoxin-Ac1-O6A & $16.12 \pm 2.49$ & $22.39 \pm 10.40$ & $31.53 \pm 7.59$ & $34.82 \pm 8.00$ & $32.03 \pm 8.56$ \\
\hline 9 & conotoxin-Ac1-R8A & $16.93 \pm 3.83$ & $20.24 \pm 5.39$ & $31.80 \pm 10.83$ & $35.93 \pm 7.64$ & $31.89 \pm 7.64$ \\
\hline 10 & conotoxin-Ac1-O9A & $16.75 \pm 3.65$ & $25.45 \pm 5.02$ & $29.52 \pm 6.69$ & $31.83 \pm 8.39$ & $29.70 \pm 7.97$ \\
\hline 11 & conotoxin-Ac1-E10A & $16.69 \pm 3.12$ & $19.84 \pm 8.99$ & $28.05 \pm 5.57 \#$ & $36.62 \pm 8.41$ & $31.61 \pm 8.41$ \\
\hline 12 & conotoxin-Ac1-N11A & $16.67 \pm 0.94$ & $25.32 \pm 9.81$ & $35.82 \pm 7.51$ & $34.24 \pm 7.90$ & $32.40 \pm 7.90$ \\
\hline 13 & conotoxin-Ac1-S12A & $15.73 \pm 3.43$ & $25.41 \pm 7.77$ & $35.24 \pm 6.58$ & $35.20 \pm 8.66$ & $31.50 \pm 7.95$ \\
\hline 14 & conotoxin-Ac1-W13A & $16.48 \pm 2.48$ & $20.78 \pm 6.92$ & $30.26 \pm 10.33$ & $35.83 \pm 7.00$ & $32.21 \pm 6.44$ \\
\hline 15 & conotoxin-Ac1-W14A & $15.96 \pm 3.60$ & $21.64 \pm 8.98$ & $28.39 \pm 5.13$ & $36.42 \pm 7.12$ & $31.73 \pm 6.40$ \\
\hline 16 & conotoxin-Ac1-T15A & $17.78 \pm 2.69$ & $19.56 \pm 8.59$ & $27.19 \pm 7.42 \#$ & $30.83 \pm 7.13$ & $26.62 \pm 6.40$ \\
\hline 17 & conotoxin-Ac1-15* & $16.06 \pm 3.31$ & $30.26 \pm 7.69$ & $39.59 \pm 9.63$ & $41.93 \pm 10.04$ & $38.03 \pm 9.11$ \\
\hline 18 & conotoxin-Ac1-E10 $\gamma$ & $16.35 \pm 3.19$ & $26.50 \pm 7.79$ & $38.44 \pm 8.80$ & $44.33 \pm 4.91 \# \#$ & $36.17 \pm 8.28$ \\
\hline 19 & conotoxin-Ac1-E10 $\gamma \mathrm{W} 14 \gamma$ & $17.90 \pm 2.84$ & $33.94 \pm 7.88 \#$ & $39.64 \pm 5.44 \#$ & $47.61 \pm 2.26 \#$ & $44.46 \pm 2.11 \# \#$ \\
\hline 20 & conotoxin-Ac1- E10 $\gamma \mathrm{W} 14 \gamma 15$ * & $15.98 \pm 3.55$ & $33.23 \pm 3.01 \#$ & $51.08 \pm 3.52 \# \#$ & $54.24 \pm 3.09 \# \#$ & $50.55 \pm 2.88$ \#\# \\
\hline
\end{tabular}

\section{Discussion}

Using NCBI website, multimode search was conducted, conotoxin-Ac1 was identified as the mature region of the reported sequence of conotoxin Ac3.1 from the same species Conus achatinus (Sequence ID: POCH24.1) [14]. The full-length cDNA of Ac3.1 was cloned from the venom-duct transcriptome with a combined PCR and RACE approach, and the amino acid sequence of Ac3.1 precursor was deduced and assigned to M-superfamily in the previous research. In this study, we performed peptides purification and sequencing to analyze and identify the mature toxins conotoxin-Ac1 and conotoxin-Ac1-O6P, located the accurate cleavage site of mature peptide formation, but also confirmed the high expression of conotoxin Ac3.1 preliminarily identified in the transcript level. It is reported in the literature that most CTxs contain disulfide bonds [15], while conotoxin-Ac1 in Conus achatinus is cysteine-free linear toxin. Linear toxins, as in Conus achatinus, are presented in high abundance. This situation is still rare and has strong research value. conotoxin-Ac1 contains 15 amino acid residues, including six aromatic amino acid residues, N-terminal (YYLY) and C-terminal (WW) are highly hydrophobic and lipophilic, while the intermediate (ROENS) is hydrophilic. Current research indicates that CTxs do not contain cysteine in cone snails can be roughly divided into six categories (Table 7). The activity of these CTxs are also different. Mo1659, which acts on the $\mathrm{K}^{+}$channel; Conomap-Vt can excite muscle tissue, but its role in receptors has not been determined; contulakin-G acts on the neurotensin receptor [16]; conantokins can block NMDAR. According to current literatures, conantokins are the only peptide-type NMDAR inhibitors with strong neuroprotective effects, and also have good anti-pain 
effects [17]. By electrophysiological experiments, we found that conotoxin-Ac1 can act on NMDAR ion channel. in addition to conantokins, which are reported in the literature, conotoxin-Ac1 is natural peptide that inhibits NMDAR activity.

Table 7. Summary of conotoxins without cysteine.

\begin{tabular}{|c|c|c|c|c|}
\hline Family & Example & Sequence & Target & Ref. \\
\hline \multirow{3}{*}{ conantokin } & conantokin-G & GE $\gamma \gamma L Q \gamma N Q \gamma L I R \gamma K S N *$ & NMDAR & [18] \\
\hline & conantokin- $\mathrm{T}$ & GE $\gamma \gamma Y Q K M L \gamma N L R \gamma A E V K K N A$ * & NMDAR & [19] \\
\hline & conantokin-L & GE $\gamma \gamma$ VAKMAA $\gamma$ LAR $\gamma$ DAVN * & NMDAR & [20] \\
\hline \multirow{2}{*}{ contulakin } & contulakin-G & ZSEEGGSNAT+KKPYIL & $\begin{array}{l}\text { Neurotensin } \\
\text { receptor }\end{array}$ & [16] \\
\hline & contulakin-Ca1 & MLTKFETKSARVKGLSFHPKRPWVL & unknown & [21] \\
\hline \multirow{3}{*}{ conorfamide } & Conorfamide-Sr1 & GPMGWVPVFYRF * & $\begin{array}{l}\text { RFamide } \\
\text { receptor }\end{array}$ & [17] \\
\hline & Conorfamide-Sr2 & GPM $\gamma \mathrm{DPL} \gamma \mathrm{IIRI}$ * & $\begin{array}{l}\text { RFamide } \\
\text { receptor }\end{array}$ & [22] \\
\hline & Conorfamide-Vc1 & HSGFLLAWSGPRNRFVRF * & $\begin{array}{l}\text { RFamide } \\
\text { receptor }\end{array}$ & [23] \\
\hline conomap & Conomap-Vt & AFVKGSAQRVAHGY * & unknown & [24] \\
\hline \multirow{2}{*}{ conophan } & conophan gld-V & AOANSVWS & unknown & [25] \\
\hline & conophan mus-V & SOANS(hVa)WS & unknown & [25] \\
\hline K-conotoxin & Mo1659 & FHGGSWYRFPWGY* & $\mathrm{K}^{\dagger}$ channel & [26] \\
\hline
\end{tabular}

Firstly, design and chemical synthesis of conotoxin-Ac1 mutants was performed. The alanine replacement method replaces each non-alanine residue site with alanine, removes the active group on the side chain, and replaces it with a small methyl group without other functional groups. This methyl group is small and can be used to identify the positions of key amino acids. We used the alanine substitution method to mutate all non-alanine residues in conotoxin-Ac1 through solid-phase synthesis of peptides, numbered 3-16. Prior results indicate that conantokins are antagonists of NMDAR, in which the C-terminal residues of this class of peptides are amidated, also, the conotoxin-Ac1 C-terminal Thr15 is mutated to amidated Thr15, which is conotoxin-Ac1-15* (17). Conantokins all contain $\gamma$-carboxyglutamic acid, which is a site for binding to metal ions. It was found that the $\gamma$-carboxyglutamic acid arrangement must meet the requirements of " $i, i+4, i+7, i+11$ "; therefore, Glu10 is mutated to $\gamma$-carboxyglutamic acid, or both Glu10 and Trp14 are mutated to $\gamma$-carboxyglutamic acid, which are conotoxin-Ac1-E10 $\gamma$ (18), conotoxin-Ac1-E10 $\gamma$ W14 $\gamma$ (19), or conotoxin-Ac1-E10 $\gamma W 14 \gamma 15$ * (20). The accuracy of each synthesized CTx polypeptide was analyzed by HPLC and MS, and then the changes in the secondary structure of conotoxin-Ac1 by each amino acid were analyzed by CD spectroscopy. In the PB buffer solution, the proportion of the $\alpha$-helix structure in conotoxin-Ac1 was $44.9 \%$. Except for conotoxin-Ac1-Y5A (7), the other mutants also had $\alpha$-helices as their main secondary structure. Although conotoxin-Ac1-Y2A (4), conotoxin-Ac1-Y3A (5) and conotoxin-Ac1-Y5A (7) all mutate tyrosine to alanine, their effects on the secondary structure are not the same, suggesting that amino acids have a secondary effect. The influence of structure is related not only to the type of amino acid but also to the site where it is located.

The main purpose of this paper is to explore the structure-activity relationship between conotoxin-Ac1 and its target. We first analyzed the effects of $10 \mu \mathrm{M}$ conotoxin-Ac1 and conotoxin-Ac1-O6P on the activity of $\mathrm{Na}^{+}, \mathrm{K}^{+}, \mathrm{Ca}^{2+}$, and NMDAR ion channels using whole-cell patch-clamp technology. The results showed that $10 \mu \mathrm{M}$ conotoxin-Ac1 and conotoxin-Ac1-O6P had almost no inhibitory effect on $\mathrm{Na}^{+}$and $\mathrm{K}^{+}, 10 \mu \mathrm{M}$ conotoxin-Ac1-O6P had an inhibitory effect on $\mathrm{Ca}^{2+}$ ion channels, and $10 \mu \mathrm{M}$ conotoxin-Ac1 had a current inhibition percentage of $56.90 \%$ on 
NMDAR ion channels. Therefore, the NMDAR ion channel is the active channel of conotoxin-Ac1. Subsequently, the effects of $10 \mu \mathrm{M}$ conotoxin-Ac1 and conotoxin-Ac1-O6P on NMDAR ion channel subtypes NR2A and NR2B were investigated. The results showed that the activity inhibition rate of the NR2B ion channel was increased by $10 \mu \mathrm{M}$ conotoxin-Ac1 to $51.69 \%$, while that of the NR2A ion channel was only $7.22 \%$, the activity inhibition rate of the NR2B ion channel was increased by $10 \mu \mathrm{M}$ conotoxin-Ac1-O6P to $10.63 \%$, while that of the NR2A ion channel was only $1.85 \%$, The result showed that the absence of the hydroxyl group on O6 of conotoxin-Ac1 causes a five-fold difference at the NMDAR subtypes NR2A and NR2B. The IC50 value of conotoxin-Ac1 on the activity of the NR2B ion channel was $8.22 \pm 0.022 \mu \mathrm{M}$. It is suggested that conotoxin-Ac1 acts on the NR2B subtype. Finally, we investigated the effect of conotoxin-Ac1 mutants on NR2B and discussed the structure-activity relationship between conotoxin-Ac1 and NR2B. Among the alanine substitution mutants numbered 3-16, conotoxin-Ac1-N1A (3), conotoxin-Ac1-O9A (10), conotoxin-Ac1-E10A (11) and conotoxin-Ac1-S12A (13) all inhibited NR2B. Compared with the inhibitory rate of conotoxin-Ac1 on NR2B, the ratio is reduced by 10 times, and the numbers $3,10,11$, and 13 are all mutated from polar amino acids to nonpolar amino acids, suggesting that polar amino acids have an important effect on the activity of conotoxin-Ac1. Although all mutations were o to A, the inhibition rate of conotoxin-Ac1-O6A (8) on NR2B was $18.98 \%$ greater than that of conotoxin-Ac1-O9A (10) on NR2B, which was approximately $4.27 \%$-approximately four times greater. The abovementioned experimental results show that $\mathrm{N} 1, \mathrm{O}$, E10, and S12 are the key active amino acids of conotoxin-Ac1, which play an important role in inhibiting the activity of NR2B. In addition, our mutants, numbered 17-20 based on the structural rule of the NMDAR antagonist conantokins did not show strong anti-NR2B activity. The experimental results suggest that conotoxin-Ac1 and conantokins are not the same NMDAR antagonist.

The results of conotoxin-Ac1 and conotoxin-Ac1-O6P animal overall activity evaluation showed that conotoxin-Ac1 and conotoxin-Ac1-O6P can significantly shorten sleep latency and prolong sleep time. It is shown that conotoxin-Ac1 and conotoxin-Ac1-O6P have stabilization effects. The analgesic activity of conotoxin-Ac1 and conotoxin-Ac1-O6P was examined by the hot-plate method and tail-burn method. The results showed that 10, 20, and $40 \mu \mathrm{g} / \mathrm{kg}$ doses of conotoxin-Ac1 and conotoxin-Ac1-O6P all had analgesic activity, and there were significant differences compared with the control group. Electrophysiological results showed that conotoxin-Ac1-O6P, and the absence of the hydroxyl group on $\mathrm{O} 6$ of conotoxin-Ac1, caused a five-fold difference at the NMDAR, but the analgesic activity of these two conotoxins are very similar, Therefore, we believe that the relationship between conotoxin-Ac1 analgesic activity and conotoxin-Ac1 inhibitory activity of NMDAR still needs to be studied in subsequent experiments. Subsequently, the analgesic activity of $10 \mu \mathrm{g} / \mathrm{kg}$ doses of the conotoxin-Ac1 mutants was analyzed by the hot-plate method. The conotoxin-Ac1 mutants numbered 3-16 were less than conotoxin-Ac1. conotoxin-Ac1-N1A (3), conotoxin-Ac1-Y2A (4), conotoxin-Ac1-Y3A (5), conotoxin-Ac1-N11A (12), and conotoxin-Ac1-S12A (13) not only reduce analgesic activity but also reach the maximum analgesic effect after $60 \mathrm{~min}$ of administration, and conotoxin-Ac1 reaches the maximum analgesia after $120 \mathrm{~min}$ of administration. The effects are notably different. In addition, the pain threshold of conotoxin-Ac1-E10A (11) and conotoxin-Ac1-T15A (16) was lower than that of conotoxin-Ac1 after $60 \mathrm{~min}$ of administration, and there were significant differences $(p<0.05)$. The above results show that N1, Y2, Y3, E10, N11, S12, and T15 play important roles in the analgesic activity of conotoxin-Ac1. Combined with electrophysiological experiments, N1 and S12 have significant effects on conotoxin-Ac1 in inhibiting NR2B and analgesic activity, specifically conotoxin-Ac1-15* (17), conotoxin-Ac1-E10 $\gamma$ (18), conotoxin-Ac1-E10 $\gamma$ W14 $\gamma$ (19), and conotoxin-Ac1-E10 $\gamma$ W14 $\gamma 15^{*}$ (20) Although these compounds have strong NR2B-inhibitory activity, they have analgesic activity, but it was higher than that of conotoxin-Ac1; furthermore, the pain thresholds of conotoxin-Ac1-E10 $\gamma \mathrm{W} 14 \gamma(19)$, conotoxin-Ac1-E10 $\gamma \mathrm{W} 14 \gamma 15^{*}(20)$ after administration for 30, 60, 120, and 180 min were significantly higher than the pain threshold of 5P1 $(p<0.05)$. It is suggested that c-terminal amidation and $\gamma$ amino acid have a strong effect on the analgesic activity of conotoxin-Ac1. 


\section{Materials and Methods}

\subsection{Isolation, Purification and Sequencing of CTXs of Conus Achatinus}

\subsubsection{Isolation and Purification of CTxs}

Conus achatinus is collected from the sea area near Qionghai, Hainan, with a body length of $6.5 \mathrm{~cm}$, a shoulder height of $5.5 \mathrm{~cm}$, and a maximum diameter of $3.5 \mathrm{~cm}$ at the center. The dissected venom tube is $7 \mathrm{~cm}$ in length, $0.5 \mathrm{~cm}$ in diameter, and $1.5 \mathrm{~cm}$ in length. The tube is cut into $2 \mathrm{~mm}$ lengths and placed in a $2 \mathrm{~mL}$ EP tube. One milliliter of $35 \%$ acetonitrile (containing $0.1 \%$ TFA) was added. Then, the samples were centrifuged at $13,000 \times \mathrm{g}$ at $4{ }^{\circ} \mathrm{C}$ for $15 \mathrm{~min}$, and the supernatant was collected and freeze-dried. The lyophilized sample was dissolved in $300 \mu \mathrm{L}$ of $30 \%$ acetonitrile (containing $0.1 \%$ TFA) and centrifuged at $12,000 \times g$ for $5 \mathrm{~min}$, and the supernatant was separated using a Superdex Peptide ${ }^{\circledR} 7.5 \times 300 \mathrm{~mm}$ column. The fractions were collected and labeled as \#1, \#2, \#3, etc, , concentrated under reduced pressure and freeze-dried for later use. The \#5 fraction was further subjected to gradient separation with an analytical column to obtain 5P1 and 5P2.

\subsubsection{Sequencing of CTxs}

MALDI-TOF-MS was used to detect the molecular weights of 5P1 and 5P2. The obtained 5P1 and 5P2 were reduced by DTT under alkaline conditions ( $\mathrm{pH} 8.0$ ), derivatized with 4-vinylpyridine, and then sequenced by an ABI491 protein sequencer using a standard Edman degradation sequencing method. Subsequently, a single toxin was digested with carboxypeptidase, $5 \mu \mathrm{g}$ of toxin peptide was dissolved in $10 \mu \mathrm{L}$ of $0.05 \mathrm{M}$ citrate buffer ( $\mathrm{pH}$ 6.0), and then $10 \mu \mathrm{L}$ of citrate buffer containing 0.5 units of carboxypeptidase $\mathrm{Y}$ was added. The reaction was carried out at a temperature of $0.2{ }^{\circ} \mathrm{C}$, and $0.2 \mu \mathrm{L}$ of the reaction solution was taken every few minutes. The reaction was terminated with CCA, and the molecular weight was detected by mass spectrometry.

\subsection{Chemical Synthesis of Conotoxin-Ac1, Its Variant and Its Mutants}

The SPPS method was used, and according to the Fmoc-TFA strategy, the synthesis method and process were performed with reference to the literature [27]. First, the alanine substitution method was used to artificially synthesize all non-alanine residues in conotoxin-Ac1, numbered 3-16. Second, according to the existing literature, the residues were mutated to the corresponding amino acids, numbered 17-20. For specific numbers and corresponding sequences, see Table 2. The synthetic peptides were verified by HPLC and MS, and the changes in the secondary structure of the peptides were analyzed by CD spectroscopy.

\subsection{Electrophysiology Experiment}

\subsubsection{Discovery of Conotoxin-Ac1 and Conotoxin-Ac1-O6P Acting on Ion Channels}

Newborn SD rat hippocampal cells were isolated for primary culture of hippocampal neurons. Isolation and culture methods were performed with reference to the literature [28]. The whole-cell patch-clamp uses an Axon700B amplifier, and the data processing software is Clampfit10.2 and Sigmaplot10.0. The glass electrode is drawn in four steps using a shutter P-97 electrode drawing instrument and thermally polished by MF-900 to facilitate sealing. conotoxin-Ac1 was dissolved in extracellular fluid at a concentration of $10 \mu \mathrm{M}$ for subsequent detection. The specific experimental operation of the patch clamp was performed in reference [29].

Recording Solution of Hippocampal Neuron Whole Cell

Intracellular and extracellular solution required for recording Nav current. External solution: $140 \mathrm{mM} \mathrm{NaCl}, 3.5 \mathrm{mM} \mathrm{KCl}, 1 \mathrm{mM} \mathrm{MgCl} 2,2 \mathrm{mM} \mathrm{CaCl}_{2}, 10 \mathrm{mM}$ Glucose, $10 \mathrm{mM}$ HEPES, $1.25 \mathrm{mM}$ 
$\mathrm{NaH}_{2} \mathrm{PO}_{4}, \mathrm{pH}=7.4$ with $\mathrm{NaOH}$. intracellular solution: $50 \mathrm{mM} \mathrm{CsCl}, 10 \mathrm{mM} \mathrm{NaCl}, 10 \mathrm{mM}$ HEPES, $60 \mathrm{mM}$ CsF, $20 \mathrm{mM}$ EGTA, $\mathrm{pH}=7.2$ with $\mathrm{CsOH}$.

Intracellular and extracellular solution required for recording Cav current. External solution: $140 \mathrm{mM}$ TEA-Cl, $2 \mathrm{mM} \mathrm{MgCl} 2,10 \mathrm{mM} \mathrm{CaCl} 2,10 \mathrm{mM}$ HEPES, $5 \mathrm{mM}$ Glucose, $\mathrm{pH}=7.4$ with TEA-OH.intracellular solution: $110 \mathrm{mM} \mathrm{CsCl}, 1 \mathrm{mM} \mathrm{MgCl} 2,10 \mathrm{mM}$ HEPES, $4 \mathrm{mM} \mathrm{Na} 2$-ATP, $10 \mathrm{mM}$ EGTA, $0.3 \mathrm{mM} \mathrm{Na}_{2}$-GTP, $5 \mathrm{mM}$ Phosphoceatine disodium salt, $7 \mathrm{mM}$ Creatine, $\mathrm{pH}=7.2$ with $\mathrm{CsOH}$. Intracellular and extracellular solution required for recording $\mathrm{Kv}$ current. External solution: $5 \mathrm{mM}$ $\mathrm{NaCl}, 140 \mathrm{mM} \mathrm{K}$-Gluconate, $1 \mathrm{mM} \mathrm{MgCl} 2,0.1 \mathrm{mM} \mathrm{CaCl}_{2}, 10 \mathrm{mM}$ EGTA, $10 \mathrm{mM}$ HEPES, $2 \mathrm{mM}$ Mg-ATP, 300nM TTX, $\mathrm{pH}=7.4$ with $\mathrm{NaOH}$. intracellular solution: $20 \mathrm{mM} \mathrm{KCl}, 115 \mathrm{mM} \mathrm{K}$-aspartic, $10 \mathrm{mM}$ HEPES, $1 \mathrm{mM} \mathrm{MgCl} 2,5$ mM EGTA, 2 mM Na 2 -ATP, $\mathrm{pH}=7.2$ with $\mathrm{KOH}$.

Intracellular and extracellular solution required for recording NMDAR current. External solution: $140 \mathrm{mM} \mathrm{NaCl}, 4 \mathrm{mM} \mathrm{KCl}, 2 \mathrm{mM} \mathrm{CaCl}, 5 \mathrm{mM}$ Glucose, $10 \mathrm{mM}$ HEPES, $\mathrm{pH}=7.4$ with $\mathrm{NaOH}$. Intracellular solution: $110 \mathrm{mM}$ CsMes, $10 \mathrm{mM} \mathrm{NaCl}, 2 \mathrm{mM} \mathrm{MgCl}$, $10 \mathrm{mM}$ HEPES, $10 \mathrm{mM}$ EGTA, $2 \mathrm{mM} \mathrm{Na}_{2}$-ATP, $0.2 \mathrm{mM} \mathrm{Na}_{2}$-GTP, $\mathrm{pH}=7.2$ with $\mathrm{CsOH}$.

\subsubsection{Screening for Conotoxin-Ac1 Acting NMDAR Subtypes}

For the expression of NR2B/NR2A in HEK293 cells, the linearized plasmids were transcribed using the Lipofectamine 2000 transcription kit, as previously described [30]. Cells were separated with TrypLE Express before patch clamp detection. A total of $3 \times 10^{3}$ cells was spread on coverslips and cultured in 24-well plates. After $18 \mathrm{~h}$, experimental detection was performed. conotoxin-Ac1 was dissolved in extracellular fluid to a concentration of $10 \mu \mathrm{M}$. The experiment used voltage clamp mode, the cell membrane potential was clamped at $-70 \mathrm{mV}$, and the recording was performed in Gap free mode for a duration of 150-300 s. Immediately after the voltage was maintained for 10-20 s, $100 \mu \mathrm{M}$ NMDA and $10 \mu \mathrm{M}$ Gly were administered followed by stimulation with $100 \mu \mathrm{M}$ NMDA and $10 \mu \mathrm{M}$ Gly and $10 \mu \mathrm{M}$ conotoxin-Ac1.

\subsubsection{Effect of Conotoxin-Ac1 Mutants on NR2B}

HEK293 cells expressing NR2B were selected, and 19 peptide samples of conotoxin-Ac1 mutants were lysed with extracellular fluid. The voltage clamp mode was used in the experiment, and the cell membrane potential was clamped at $-70 \mathrm{mV}$ and recorded in Gap free mode, duration a of 150 to $300 \mathrm{~s}$. Immediately after the voltage was maintained for 10-20 s, $100 \mu \mathrm{M}$ NMDA and $10 \mu \mathrm{M}$ Gly were administered followed by $100 \mu \mathrm{M}$ NMDA and $10 \mu \mathrm{M}$ Gly and $0.3,1,3,10$, and $30 \mu \mathrm{M}$ conotoxin-Ac1 for stimulation. The remaining 19 peptide samples were formulated as $100 \mu \mathrm{M}$ NMDA and $10 \mu \mathrm{M}$ Gly and $10 \mu \mathrm{M}$ test peptide samples for stimulation.

\subsection{Animal Experiment}

\subsubsection{Animal Overall Activity}

The method of cranial administration was used to observe the behavior of animals to evaluate the toxins. conotoxin-Ac1 and conotoxin-Ac1-O6P were dissolved in physiological saline. Thirty Kunming mice of similar size, $18 \pm 2 \mathrm{~g}$, male and female. All animal studies were in accordance with the NIH guide for the care and use of laboratory animals and were approved by the Beijing Institute of Technology Animal Institute Committee (SYXK-BIT-20161008001). Mice were selected and randomly divided into 5 groups, namely, the control group, conotoxin-Ac1 at 250 and $500 \mu \mathrm{g} / \mathrm{kg}$ doses, and conotoxin-Ac1-O6P at 250 and $500 \mu \mathrm{g} / \mathrm{kg}$ doses. A graduated needle was used to inject the corresponding volume into the lateral ventricle, and the control group was injected with the same dose of normal saline. After the injection was completed, the mice were returned to their cages, and their behaviors and symptoms were observed and recorded. If the mouse is not supine within $1 \mathrm{~min}$, it means that the righting reflex has disappeared. Time was recorded as the sleep latency; the duration of 
the disappearance of the righting reflex was recorded as the sleep time, and the sleep latency and sleep time of each group falling asleep were recorded separately.

\subsubsection{Animal Analgesic Activity}

Analgesic Activity of Conotoxin-Ac1 and Conotoxin-Ac1-O6P Detected by the Hot-Plate Method

The analgesic activity of conotoxin-Ac1 and conotoxin-Ac1-O6P was evaluated with the classical mouse hot-plate method [31]. The pain threshold, the latency at which the mouse licked its hind paw or jumped, was determined on a $55^{\circ} \mathrm{C}$ hot plate. Mice with a threshold $<30 \mathrm{~s}$ were divided into eight groups, and each group contained six mice. By intracranial administration, mice in group 1 were given saline as a control, while mice in group 2 were given morphine at a $10 \mu \mathrm{g} / \mathrm{kg}$ dose as a positive control. Groups 3, 4, and 5 were given conotoxin-Ac1 at 10, 20, and $40 \mu \mathrm{g} / \mathrm{kg}$ doses, and groups 6, 7, and 8 were given conotoxin-Ac1-O6P at 10, 20, and $40 \mu \mathrm{g} / \mathrm{kg}$ doses. The response time (RT) was determined at 15 , $30,60,120$, and 180 min after administration. Data are expressed as means $\pm \mathrm{SD}$, and the t-test was used to determine statistical significance.

Analgesic Activity of Conotoxin-Ac1 and Conotoxin-Ac1-O6P Detected by the Tail-Flick Method

The analgesic activity of conotoxin-Ac1 and conotoxin-Ac1-O6P was evaluated with the classical mouse tail-flick method [32]. The pain threshold, the latency at which the mouse licked its hind paw or jumped, was determined on a $55{ }^{\circ} \mathrm{C}$ hot plate. The rats were placed in a fixed cylinder, the tail tips of the mice were exposed, and $3 \mathrm{~cm}$ of the tail tips of the mice were placed into a preheated water bath at $55{ }^{\circ} \mathrm{C}$. Mice with a threshold $<2 \mathrm{~s}$ were divided into seven groups, and each group contained six mice. By intracranial administration, mice in group 1 were given saline as a control, while mice in group 2 were given morphine at a $1 \mathrm{mg} / \mathrm{kg}$ dose as a positive control. Groups 3, 4, and 5 were given conotoxin-Ac1 at 10, 20, and $40 \mu \mathrm{g} / \mathrm{kg}$ doses, and groups 6, 7, and 8 were given conotoxin-Ac1-O6P at 10, 20 , and $40 \mu \mathrm{g} / \mathrm{kg}$ doses. The tail-flick response time was determined at 15, 30, 60, 120, and $180 \mathrm{~min}$ after administration. Data are expressed as means $\pm \mathrm{SD}$, and the $\mathrm{t}$-test was used to determine significance.

Analgesic Activity of Conotoxin-Ac1 Mutants Detected by the Hot-Plate Method

The analgesic activity of conotoxin-Ac1 mutants was evaluated with the classical mouse hot-plate method [31]. The pain threshold, the latency at which the mouse licked its hind paw or jumped, was determined on a $55^{\circ} \mathrm{C}$ hot plate. Mice with a threshold $<30 \mathrm{~s}$ were divided into eight groups, and each group contained six mice. By intracranial administration, mice in each group were given each mutant at a $10 \mu \mathrm{g} / \mathrm{kg}$ dose. The response time (RT) was determined at 15, 30, 60, 120, and $180 \mathrm{~min}$ after administration. Data are expressed as means $\pm \mathrm{SD}$, and the t-test was used to determine statistical significance.

\subsection{Statistical Analysis}

The results are expressed as means \pm standard deviation. The significance values were calculated using SPSS 17.0 software. Data were analyzed by homogeneity of variance and one-way analysis of variance (ANOVA). P-values less than 0.05 were considered to be significant.

Supplementary Materials: The following are available online at http://www.mdpi.com/1660-3397/18/3/135/s1, Figure S1: Isolation of crude conotoxins from Conus achatinus, Figure S2: HPLC analysis of fraction 5, Figure S3: The co-elution of synthetic conotoxin-Ac1 and wild conotoxin-Ac1, Figure S4: The co-elution of synthetic conotoxin-Ac1-O6P and wild conotoxin-Ac1-O6P, Table S1: Analgesic activity of conotoxins conotoxin-Ac1 and conotoxin-Ac1-O6P, as determined by the hot-plate test, Table S2: Analgesic activity of conotoxins conotoxin-Ac1 and conotoxin-Ac1-O6P, as determined by the tail-flick test, supplemental MS data: The MS data fugures of synthetic conotoxin-Ac1-O6P and its mutants.

Author Contributions: X.L., G.Y. and K.W. conceived and designed the experiments; X.L., G.Y. and Y.L. performed the experiments; X.L., K.W. and H.J. analyzed the data; X.L., G.Y., K.W. and Y.L. contributed reagents/materials/analysis tools; X.L. and X.W. wrote the paper with input from all authors. All authors have read and agreed to the published version of the manuscript. 
Funding: This research received no external funding.

Conflicts of Interest: The authors declare no conflict of interest.

\section{References}

1. Qiuyun, D. Progress in toxicology and pharmacology of conotoxins. Chin. J. Pharmacol. Toxicol. 2016, 12, 1397-1410.

2. Kim, H.W.; McIntosh, J.M. Alpha6 nAChR subunit residues that confer alpha-conotoxin BuIA selectivity. FASEB J. 2012, 26, 4102-4110. [CrossRef] [PubMed]

3. Yu, S.; Li, Y.; Chen, J.; Zhang, Y.; Tao, X.; Dai, Q.; Wang, Y.; Li, S.; Dong, M. TAT-Modified omega-conotoxin MVIIA for crossing the blood-brain barrier. Mar. Drugs 2019, 17, 286. [CrossRef] [PubMed]

4. Boccaccio, A.; Conti, F.; Olivera, B.M.; Terlau, H. Binding of kappa-conotoxin PVIIA to Shaker K+ channels reveals different $\mathrm{K}+$ and $\mathrm{Rb}+$ occupancies within the ion channel pore. J. Gen. Physiol. 2004, 124, 71-81. [CrossRef] [PubMed]

5. Pan, X.; Li, Z.; Huang, X.; Huang, G.; Gao, S.; Shen, H.; Liu, L.; Lei, J.; Yan, N. Molecular basis for pore blockade of human $\mathrm{Na}(+)$ channel Nav1.2 by the mu-conotoxin KIIIA. Science 2019, 363, 1309-1313. [CrossRef] [PubMed]

6. Deuis, J.R.; Dekan, Z.; Inserra, M.C.; Lee, T.H.; Aguilar, M.I.; Craik, D.J.; Lewis, R.J.; Alewood, P.F.; Mobli, M.; Schroeder, C.I.; et al. Development of a muO-Conotoxin analogue with improved lipid membrane interactions and potency for the analgesic sodium channel NaV1.8. J. Biol. Chem. 2016, 291, 11829-11842. [CrossRef] [PubMed]

7. Bulaj, G.; DeLaCruz, R.; Azimi-Zonooz, A.; West, P.; Watkins, M.; Yoshikami, D.; Olivera, B.M. Delta-conotoxin structure/function through a cladistic analysis. Biochem. Us 2001, 40, 13201-13208. [CrossRef] [PubMed]

8. Stewart, M.J.; Harding, B.I.; Adamson, K.J.; Wang, T.; Storey, K.B.; Cummins, S.F. Characterisation of two conopressin precursor isoforms in the land snail, Theba pisana. Peptides 2016, 80, 32-39. [CrossRef]

9. Reyes-Guzman, E.A.; Vega-Castro, N.; Reyes-Montano, E.A.; Recio-Pinto, E. Antagonistic action on NMDA/GluN2B mediated currents of two peptides that were conantokin-G structure-based designed. BMC Neurosci. 2017, 18, 44. [CrossRef]

10. McIntosh, J.M.; Jones, R.M. Cone venom-from accidental stings to deliberate injection. Toxicon 2001, 39, 1447-1451. [CrossRef]

11. Gowd, K.H.; Dewan, K.K.; Iengar, P.; Krishnan, K.S.; Balaram, P. Probing peptide libraries from Conus achatinus using mass spectrometry and cDNA sequencing: Identification of delta and omega-conotoxins. J. Mass Spectrom. 2008, 43, 791-805. [CrossRef] [PubMed]

12. Liu, L.; Chew, G.; Hawrot, E.; Chi, C.; Wang, C. Two potent alpha3/5 conotoxins from piscivorous Conus achatinus. Acta Biochim. Biophys. Sin. (Shanghai) 2007, 39, 438-444. [CrossRef] [PubMed]

13. Turner, R.J.; Freeman, S.E. Factors affecting the muscle depolarization due to Conus achatinus toxin. Toxicon 1974, 12, 49-55. [CrossRef]

14. Wu, X.; Zhou, M.; Peng, C.; Shao, X.; Guo, Z.; Chi, C. Novel conopeptides in a form of disulfide-crosslinked dimer. Peptides 2010, 31, 1001-1006. [CrossRef] [PubMed]

15. Terlau, H.; Olivera, B.M. Conus venoms: A rich source of novel ion channel-targeted peptides. Physiol. Rev. 2004, 84, 41-68. [CrossRef]

16. Craig, A.G.; Norberg, T.; Griffin, D.; Hoeger, C.; Akhtar, M.; Schmidt, K.; Low, W.; Dykert, J.; Richelson, E.; Navarro, V.; et al. Contulakin-G, an O-glycosylated invertebrate neurotensin. J. Biol. Chem. 1999, 274, 13752-13759. [CrossRef]

17. Maillo, M.; Aguilar, M.B.; Lopez-Vera, E.; Craig, A.G.; Bulaj, G.; Olivera, B.M.; de la Cotera, E.H. Conorfamide, a Conus venom peptide belonging to the RFamide family of neuropeptides. Toxicon 2002, 40, 401-407. [CrossRef]

18. Balsara, R.; Li, N.; Weber-Adrian, D.; Huang, L.; Castellino, F.J. Opposing action of conantokin-G on synaptically and extrasynaptically-activated NMDA receptors. Neuropharmacology 2012, 62, 2227-2238. [CrossRef]

19. Warder, S.E.; Blandl, T.; Klein, R.C.; Castellino, F.J.; Prorok, M. Amino acid determinants for NMDA receptor inhibition by conantokin-T. J. Neurochem. 2001, 77, 812-822. [CrossRef] 
20. Jimenez, E.C.; Donevan, S.; Walker, C.; Zhou, L.M.; Nielsen, J.; Cruz, L.J.; Armstrong, H.; White, H.S.; Olivera, B.M. Conantokin-L, a new NMDA receptor antagonist: Determinants for anticonvulsant potency. Epilepsy Res. 2002, 51, 73-80. [CrossRef]

21. Yao, G.; Peng, C.; Zhu, Y.; Fan, C.; Jiang, H.; Chen, J.; Cao, Y.; Shi, Q. High-throughput identification and analysis of novel conotoxins from three vermivorous cone snails by transcriptome sequencing. Mar. Drugs 2019, 17, 193. [CrossRef] [PubMed]

22. Aguilar, M.B.; Luna-Ramirez, K.S.; Echeverria, D.; Falcon, A.; Olivera, B.M.; de la Cotera, E.P.H.; Maillo, M. Conorfamide-Sr2, a gamma-carboxyglutamate-containing FMRFamide-related peptide from the venom of Conus spurius with activity in mice and mollusks. Peptides 2008, 29, 186-195. [CrossRef] [PubMed]

23. Robinson, S.D.; Safavi-Hemami, H.; Raghuraman, S.; Imperial, J.S.; Papenfuss, A.T.; Teichert, R.W.; Purcell, A.W.; Olivera, B.M.; Norton, R.S. Discovery by proteogenomics and characterization of an RF-amide neuropeptide from cone snail venom. J. Proteom. 2015, 114, 38-47. [CrossRef]

24. Dutertre, S.; Lumsden, N.G.; Alewood, P.F.; Lewis, R.J. Isolation and characterisation of conomap-Vt, a D-amino acid containing excitatory peptide from the venom of a vermivorous cone snail. FEBS Lett. 2006, 580, 3860-3866. [CrossRef] [PubMed]

25. Pisarewicz, K.; Mora, D.; Pflueger, F.C.; Fields, G.B.; Mari, F. Polypeptide chains containing D-gamma-hydroxyvaline. J. Am. Chem. Soc. 2005, 127, 6207-6215. [CrossRef] [PubMed]

26. Sudarslal, S.; Singaravadivelan, G.; Ramasamy, P.; Ananda, K.; Sarma, S.P.; Sikdar, S.K.; Krishnan, K.S.; Balaram, P. A novel 13 residue acyclic peptide from the marine snail, Conus monile, targets potassium channels. Biochem. Biophys. Res. Commun. 2004, 317, 682-688. [CrossRef] [PubMed]

27. Turner, M.W.; Marquart, L.A.; Phillips, P.D.; McDougal, O.M. Mutagenesis of alpha-Conotoxins for enhancing activity and selectivity for nicotinic acetylcholine receptors. Toxins 2019, 11, 113. [CrossRef] [PubMed]

28. Christenson, W.Z.; Tetzlaff, M.R.; Krook-Magnuson, E. Novel long-range inhibitory nNOS-expressing hippocampal cells. eLife 2019, 8. [CrossRef] [PubMed]

29. Lu, Y.; Dang, S.; Wang, X.; Zhang, J.; Zhang, L.; Su, Q.; Zhang, H.; Lin, T.; Zhang, X.; Zhang, Y.; et al. $\mathrm{NO}$ involvement in the inhibition of ghrelin on voltage-dependent potassium currents in rat hippocampal cells. Brain Res. 2018, 1678, 40-46. [CrossRef] [PubMed]

30. Peigneur, S.; Tytgat, J. When cone snails and spiders meet: Design of selective and potent sodium channel inhibitors. Toxicon 2014, 91, 170. [CrossRef]

31. Zhu, X.; Bi, J.; Yu, J.; Li, X.; Zhang, Y.; Zhangsun, D.; Luo, S. Recombinant expression and characterization of $\alpha$-Conotoxin LvIA in Escherichia coli. Mar. Drugs 2016, 14, 11. [CrossRef] [PubMed]

32. Karna, S.R.; Kongara, K.; Singh, P.M.; Chambers, P.; Lopez-Villalobos, N. Evaluation of analgesic interaction between morphine, dexmedetomidine and maropitant using hot-plate and tail-flick tests in rats. Vet. Anaesth. Analg. 2019, 46, 476-482. [CrossRef] [PubMed] 